\title{
Political Participation through Inclusiveness: An Exploration of Politics of Ethnic-Discrimination in Nigeria
}

\author{
Dr. Olakunle Michael Folami ${ }^{1}$, Dr. Fasuwon, Adebayo ${ }^{2}$, Olugbenga Olaseinde ${ }^{3}$
}

\author{
${ }^{1}$ Department of Criminology \& Security Studies, Adekunle Ajasin University, Akungba Akoko, Ondo State, Nigeria. \\ ${ }^{2}$ Department of Political Science, Adekunle Ajasin University, Akungba Akoko, Ondo State, Nigeria. \\ ${ }^{3}$ Department of Sociology, Adekunle Ajasin University, Akungba Akoko, Ondo State, Nigeria.
}

Received: 11 Nov 2021; Received in revised form: 05 Dec 2021; Accepted: 10 Dec 2021; Available online: 21 Dec 2021 (C)2021 The Author(s). Published by Infogain Publication. This is an open access article under the CC BY license (https://creativecommons.org/licenses/by/4.0/).

\begin{abstract}
Political participation is characterized by ethnic-discrimination in Nigeria. Electoral processes and nomination of candidates at election often laced with ethnicity and discrimination. Selection of candidates for political offices usually follows politics of ethnicity. The constitutional provision which ensures equity often suspended whenever candidates were presented for electoral offices. This study examines causes of ethnic consideration as the basis for political participation. This study argues that recognition of every community member would enhance qualitative political participation in Nigeria. Recognition Theory, a social justice theoretical framework, was used in this study to explain concepts such as discrimination, ethnicity and participatory politics, and their centrality to democratic values in Nigeria. The theory provides explanation for the inequalities in political participation such as inaccessibility, disassociation, discrimination, prejudice and non-participation. Qualitative method of data collection was adopted in this study. Unstructured interview guide was designed to collect data from one hundred and twenty-five participants. The participants were selected from the capital of States selected for this study such as Benin, Suleja, Ilorin, Owerri, Ikeja and Osogbo. This paper found that voting patterns were influenced by factors such as ethnicity, favoritism, godfather, bribery and others. It was also found that candidates' choice for elections is determined by godfather, ethnicity, age, religion rather that a ten-year residency dictated by the constitution. It was concluded that inclusiveness without discrimination such as ethnicity, region, godfather, state of origin and gender could galvanize equal political participation. This paper finally concluded that political participation though inclusiveness can reduce politics of ethnicdiscrimination in Nigeria.
\end{abstract}

Keywords_ethnicity, politics, participation, recognition, equity, godfather, discrimination.

\section{INTRODUCTION}

Nigeria is a multi-ethnic country with over 250 ethnic groups (Mustapha, 2006). The major ethnic groups are the Yoruba in the Southwest, the Hausa in the North, and the Igbo in the Southeast (Mustapha, 2005). At independence, the granting of citizenship rights was enshrined in the constitution. Citizenship rights were matched with the preservation of ethnicity, which predicated on paternity (Oyewo \& Olaoba, 1993). Ethnicity plays a major role in the political participation of non-indigenes in Nigeria. Political discrimination against non-indigenes is well pronounced in various regions of the country. Most often ethnicity has led to political conflict between the indigenes and non-indigenes. The effects of ethnic politics have become a threat to fledgling democracy in Nigeria. This study therefore sets to examine causes of ethnic consideration as the basis of political participation. This study argues that recognition of every community member would enhance qualitative political participation in Nigeria. In this study, discrimination as a concept is adopted to examine ethnic based politics processes. This study therefore, designs to support inclusive political 
participation base on nationalism, achievement, patriotism and altruism. To examine historical antecedent of ethnicbased politics in Nigeria. To identify how ethnicity affects political participation in Nigeria and to suggest ways by which inclusiveness could enhance political participation in Nigeria.

In this study, I conceptualized ethnic politics as a nonrecognition of generalized others during political processes. I also used Recognition Theory as analytical tool to explain why generalized community member's participation is expedient to democratic development. Recognition Theory posits that self-realisation is possible through intersubjective recognition (Taylor, 1994). Intersubjective recognition confers legitimate rights on individuals who have claims to social and political benefits (Honneth, 2001). Fraser (2003) says that participatory parity should be the first step toward equality. It is when the individual is recognized as equal partner that he / she could participate equally in social and political affairs (Fraser, 1997). Therefore, Recognition Theory is adopted in this study to explain inequalities in political participation in Nigeria such as inaccessibility, disassociation, discrimination, prejudice and nonparticipation. This study attempts to answer the following research questions: What factor determines political participation in Nigeria? How ethnicity is used to determine political participation in Nigeria? Which forms of discrimination undermines political participation in Nigeria? And what can be done to enhance equal political inclusiveness in Nigeria?

This paper is divided into sections and subsections. Section one provides introduction. Section two discusses context. Section three explains recognition and participatory politics. Section four examines qualitative method while section five discusses findings. The last section provides the conclusion. Therefore, this paper sets to conclude that political participation though inclusiveness can reduce politics of ethnic-discrimination in Nigeria.

\section{Context}

Nigeria became a British colony as a result of the scramble and partition of Africa at a conference which took place in Berlin in 1885 . The country was divided into the Southern protectorate, the Northern protectorate and the Lagos colony by the British between 1862 and 1885 (Hamzat, 2012). On January 1, 1901 Nigeria officially became a British colony (Chatterjee, 1986). According to Robinson, (1961), the protectorates and the Lagos colony were three distinct administrative areas before the amalgamation. The colony of Lagos and the southern protectorate were joined together in 1906. General Lord Laggard amalgamated the Southern protectorate, the Northern protectorate and the
Lagos colony for administrative purposes. The amalgamation of the protectorates and the Lagos colony took place in 1914 (Falola and Heaton, 2008). The amalgamation of the protectorates gave birth to a geographical expression called Nigeria. There are over two hundred and fifty ethnic tribes in Nigeria. The three major tribes are: Yoruba, Igbo and Hausa/Fulani (Everyculture.com, 2007). The three major ethnic groups have dominated the socio-political landscape of the country since the colonial era. It was Governor Arthur Richard that introduced regionalism to Nigeria by creating three regions in 1946, namely: the Western, the Eastern and the Northern region. The three regions are dominated by the three major ethnic groups. The Niger Delta region was part of the old Eastern region with exception of Ondo, Edo and Delta State (Sagay, 2004). Mwakikagile (2001) notes that before independence in 1960, a federation of three regions had evolved. According to Jekayinfa (2002) ethnic tension began in Nigeria during the colonial era when one ethnic group was favoured over others. This is reflected in the struggle for socio-political economic development among the various ethnic groups. Ethnicity has become a major problem in Nigeria and has adversely affected issues concerning the development of the country. Arguably, and given what has happened historically, the three hegemonic groups Yoruba and Hausa are usually united to conspire when it comes to the issues concerning power sharing. They usually pay "lip-service" to the inclusion of other region (Okolo, 2008).

Nigeria became independent on October $1^{\text {st }}, 1960$, as a federation of three regions, and later became a federal republic in 1963. In 1963, a military coup ushered in a military regime with the creation of an additional region, the Mid-western region (World Leader, 2003). The three regions were divided further into twelve States by the Military Government of General Yakubu Gowon (Davies, Danmole \& Taiwo, 1995). By 1976, General Murtala Mohammed divided Nigeria further into nineteen States (Egbosiuba, 2012). The number of States in the country were increased to twenty-one in 1987 by General Ibrahim Badamosi Babangida regime, and later increased to thirty States by the same administration in 1991 (Falola, 1999). The three major ethnic groups had a fair share of the newly created States. It was General Sani Abacha that further divided the country into thirty-six States and categorised them into six geo-political regions, namely: Southwest, Southeast, Southsouth, Northeast, Northwest and NorthCentral (Ojukwu \& Nwaorgu, 2013).

\section{Recognition and Participatory Politics}

Recognition Theory, a social justice theoretical framework, is used in this study to explain concepts such as 
discrimination, ethnicity and participatory politics, and their centrality to democratic culture in Nigeria. The theory provides explanation for the inequalities in political participation such as inaccessibility, disassociation, discrimination, prejudice and non-participation. Participatory politics seeks to explain recognition of peoples' right to freedom of choice, right to vote, right to be voted for, and ensuring distribution of political offices among members of the community without ethnic bias and prejudice. Also, participatory democracy provides recognition for citizens because mechanism such as freedom is explicitly and primarily carried out by the state.

Hegel works sparked the interest of contemporary understanding of recognition more than his predecessors, such as Johann Fichte in his foundations of Natural Rights. Fichte produced a thoroughly intersubjective ontology of humans and demonstrated that freedom and selfunderstanding are dependent upon recognition (Dyde, 2001). Following this conception, Hegel in his work on Phenomenology of Spirit says 'Self-consciousness' exists in itself and for itself, in that, and by the fact that it exists for itself for another self-consciousness: that is to say, it is only by being acknowledged or "recognised" (Dyde, 2001). Self-esteem, including one's sense of freedom and sense of self-realisation, is not an issue of self-analysis (McQueen, 2011). Rather, understanding oneself requires the recognition of another.

The idea of recognition developed further in Hegel's works on the Elements of the Philosophy Rights' (Dyde, 2001). According to McQueen (2011) recognition becomes contingent on social and practical accomplishment. It is an intersubjectively mediated achievement, which is never simply given or guaranteed, but always dependent upon equal relations with others (McQueen, 2011). This codependency results in mutual relations of recognition, which are the condition for understanding oneself as a genuinely free being, albeit one that acknowledges, and thus adjusts itself, to the freedom of others (McQueen, 2011). As a result, the self-consciousness acknowledges them as mutually recognising one another. Hegel characterises this mutuality, which cannot be coerced but rather has to be freely given and received as being at home in the other (McQueen, 2011; Dyde, 2001). It is through the intersubjective recognition of our freedom that rights are actualised. Rights are not instruments of freedom; rather they are the concrete expression of it. Hegel says recognition is the mechanism by which our social existence is generated (Stern, 2002). Just recognition is best explained by what Hegel called "intersubjective recognition".

Recognition Theory advances from atomistic to intersubjective, mechanical and dialogical understandings between individuals because people's identity is shaped precisely through interaction with others in society. And it is through our feelings of self-worth, self-respect and selfesteem that we are positively recognised for whom we are (McQueen, 2011). The contemporary understanding of recognition theory started with Charles Taylor's essay titled "Multiculturalism and the Politics of Recognition", which was first published in 1992 (Taylor, Gutmann \& Taylor, 1994). In his essay, Taylor argues that recognition can be deployed to address issues generated by identity (Morrison, 2011; Andersen \& Siim, 2004). It is a reciprocal relation where citizens see themselves as equal with legitimate claims to recognition (McQueen, 2011).

Political theories of recognition attempt to reconfigure the concept of rights in terms of due or withheld recognition. Margalit (2001:12) defines "recognition as an act of intellectual apprehension, a form of identification, and the act of acknowledging or respecting another being, such as when we 'recognise' someone's status, achievements or rights." Recognition requires that we authorise someone to confer recognition. Similarly, one can gain authority and responsibility by asking others for recognition (Margalit, 2001). Consequently, one has authority only if one is genuinely recognised by others. Reciprocity and mutuality are necessary conditions of appropriate recognition (McQueen, 2011). There are two ways by which we can categorise recognition.

1. Individual recognition, which Taylor, Gutmann \& Taylor (1994) refer to as intersubjective recognition. Honneth (1992) also called it a theory of identity and self-esteem. I call it a primary level of gender recognition in this study because it forms the basis for the recognition of women.

2. Group recognition is referred to as status parity participation; it is also known as participatory parity (Fraser (1997:12). I call this a secondary level of gender recognition.

The two categorisations complement each other. Community recognition by others is essential to the development of self-consciousness and identity. Without a community sense of identity and self-esteem, it will be difficult to achieve (Morrison, 2011). Taylor's analysis of recognition is related to identity formation and sense of self. They define identity as a means by which individuals understand who they are, and their fundamental characteristics as human beings (1992). We owe our integrity as people to receiving the approval or recognition 
of others (Taylor, 1992). When we are insulted or degraded in some way, we are denied recognition, and our positive understanding of our self is deflated (McQueen, 2011). When we are denied recognition, or are "not recognised," we suffer an injury in relation to our identity, and it can be a form of oppression, imposing someone in a false, distorted, and reduced mode of being (Taylor, Gutmann \& Taylor, 1994:25).

The idea of equal recognition by Taylor (Taylor, Gutmann \& Taylor, 1994:26) is dualistic and he uses this insight to explain a politics of equal recognition. He identifies two different ways of equal recognition. He called the first one a politics of equal dignity, or a politics of universalism. The second proposition is the politics of difference. Taylor's argument on equal recognition finds a place in the universalistic value of fundamental human rights. He recognises (1) the politics of equal dignity or a universalistic politics, which move towards equalisation of all rights and entitlement and, (2) the politics of difference in which the uniqueness of each individual or group is recognised (Taylor, 1992). According to Taylor (1992), one consequence of this politics of difference is that certain rights will be assigned to specific groups but not others. Taylor refers to this idea of uniqueness as the idea of authenticity. It is instructive to understand if recognition could serve group interests, the impact of "nonrecognition" on individual interests, and the consequences of group "nonrecognition" on individuals, and vice-versa. McQueen (2011) argues that Taylor gives little consideration for a group as an object of recognition but his general emphasis is on individual rights and recognition. Drawn from the work of Hegel, he emphasises how recognition can be achieved through inter-subjective identity.

Recognition theorists have identified two forms of recognition, namely: (1) generative (objective); and, (2) responsive (subjective). A generative form of recognition focuses on the ways in which recognition produces or generates reasons for actions or self-understandings (Laitinen, 2002:6). A responsive form of recognition focuses on the ways in which recognition acknowledges pre-existing features of a person (Markell, 2000). Demand for recognition is a response-model which is produced and justified through pre-existing characteristics of a person. With the generative-model, it is the act of recognition itself, which confers those characteristics onto a person through their being recognised as such (Appiah, 1994: 149). The former is a case of a person "knowing" while the latter is a case of a person "making" (Laitinen, 2002; Markell, 2000; McQueen, 2011).

The intersubjective recognition analysis continues in the work of Axel Honneth (1995), on The Struggle for Recognition: the Grammar of Social Conflicts. Honneth identified three forms of recognition: love, rights, and solidarity. These forms of recognition are intersubjectively mediated. The argument is if an individual is shown love, respect and self-esteem by others, then they can acquire the self-confidence, self-respect and self-esteem necessary for self-realisation (Honneth, 1992). For Honneth, justice or well-being of a society is proportionate to its ability to secure conditions of mutual recognition. This is started with personal identity-formation, and later, individual selfrealisation. Honneth(1995) believes that 'a sufficiently differentiated theory of recognition' can deal with matters of justice. Honneth states that the three levels of interaction (love, rights, and solidarity) are associated with these patterns of recognition (Honneth, 1995: 92; also Honneth, 2007: 129-142). Love refers to how our basic physical and emotional needs are met by the significant others, such as close friends, family and lovers (Honneth, 1992:194). When we have these, we have a basic selfconfidence, and vice versa. Rights refer to the moral responsibility that develops through our moral relations with others (Honneth, 1992:194). An individual learns to see him / herself from the perspective of his / her partner through interaction as a bearer of equal rights (Honneth, 1992:195). The denial of rights through social and political injustice can threaten one's sense of being a fully active, equal and respected member of society (McQueen, 2011). Lastly, Honneth (1995) says that solidarity includes our traits and abilities. He says that it is essential for developing our self-esteem and how we become 'individualised', for it is precisely our personal traits and abilities that define our personal difference. Further, Honneth adds that it is only due to the cumulative acquisition of basic self-confidence, of self-respect, and of self-esteem that a person can come to see himself or herself, unconditionally, as both an autonomous and an individualised being and to identify with his or her goals and desires (Ibid:169). According to Honneth, the denial of recognition provides the motivational and justificatory basis for social struggles (1992:170). Honneth's selfrealisation claims are significantly more restricted than justice claims precisely because they are based on a more "historically specific horizons value" (Fraser\& Honneth,2003; 2000; 1997).

Intersubjective recognition is useful to political participation in different ways: first, to determine individual participation is necessary in politics; second, to know what kinds of involvement necessary for individual in politics (elective or appointment); third, to categorise the individuals that requires identity; and lastly, to explain how equal participation can be achieved. One major 
criticism against intersubjective recognition, however, is that it cannot accommodate group. The principle of selfrealisation reduces rights to a mere micro phenomenon which cannot accommodate and explain macro discrimination experienced by a group. Applying this principle to democracy, intersubjective recognition seems to be incapable of explaining ethnic participation because the basic aim of participatory politics is the general satisfaction of a group. The next theory of recognition is participatory paradigm. The paradigm provides explanation for the recognition of both individual and group in electoral processes.

Participatory parity, Fraser's theory is founded on a different principle of recognition called 'parity of participation', according to which “justice requires social arrangements that permit all to participate as peers in social life (Fraser\& Honneth, 2003)." Fraser (1997) identifies three principles of recognition. The first principle refers to what she calls the 'status order' of society. The principle advocates the removal of existing status forms of inequalities which act as a block to parity of participation. The second principle refers to what she calls the 'economic structure of society'. Economic order is provided if the society have the resources they need to actualize recognition. The third principle is 'representation'. The principle promotes how political decisions and political boundaries could facilitate recognition (Fraser, 2003). The reason why the third dimension was introduced to recognition theory by Fraser is that there are ranges of cases of injustice which cannot be successfully addressed within a recognition framework (Fraser \& Honneth, 2007:3).

Generally, based on Fraser's principles of justice, it can be argued that recognition is obtained if members of the society possess the status, resources and voice needed to be equal in socio-political and economic arrangements (Fraser, 2007:4). Fraser's major preoccupation is whether recognition theory would be able to accommodate equal political rights. Fraser (2007) projects that recognition theory should take care of cultural injustice. According to her, the recognition paradigm seems to tilt towards redistribution injustice, which is rooted in the construction of participatory parity. McQueen (2011) identifies recognition with social status, and provides a notion of "parity participation". In effect, recognition is required in order to guarantee that all members of society have an equal participation in social life. For example, political inclusions is possible under the conditions highlighted by Fraser, which include social order, economic order and representation.
Examining Recognition Theory as a whole, there are gaps in connection between institutionalised norms and political pariticipation. Recognition theories have to tackle institutionalised culture simultaneously with political participation. Fraser's analysis of recognition and equality is criticized by Young as a false dualism that does not reflect reality. He argues that rather than acting counter to participation, a politics of recognition serves as a means of economic and social equality (Young, 1990). Recognition theories fail to discuss the processes of institutionalisation and internalisation of the norms which discourage participatory parity, which can lead to non-recognition. The theory also does not attempt to deconstruct institutionalised culture which informs non-recognition of peoples' rights. It treats participatory parity as an automatic Social Action Theory (Morrison, 2011). Recognition theory has also been accused of using stereotypical descriptions of marginalised group, such as subordinate, underclass, pitied, subaltern, etc. However, recognition propositions, as related to post-liberal multiculturalism have been identified with the Western culture, to promote human values within a democratic culture. It has given voices to ethnic groups across the world to seek attention to discrimination against democratic participation in other parts of the world.

\section{METHOD}

This section of the paper is divided into various subsections such as location, participants, data collection and data analysis.

Location

There are six geo-political regions with thirty-six states in Nigeria. Critical case sampling method was used to select six states where the data for this study was collected, namely: Edo; Abuja; Kwara; Imo; Osun; and Lagos. Data collection took a month in the selected study areas.

\section{Participants}

Purposive method of sampling was used to select one hundred and twenty-five participants among nonindigenes, indigenes, and political actors. The participants were selected from the capital of the states selected for this study, except Abuja the nation capital territory, that is: Edo (Benin); Abuja (Suleja); Kwara (Ilorin); Imo (Owerri); Osun (Osogbo); and Lagos (Ikeja). The followings were distribution of participants: 
Fig.1: Distribution of Participants

\begin{tabular}{|l|l|l|l|l|l|l|l|}
\hline Participants & \multicolumn{9}{|c|}{ Locations } & Total \\
\hline & Benin & Suleja & Ilorin & Owerri & Ikeja & Osogbo & \\
\hline Indigenes & 9 & 9 & 9 & 5 & 9 & 6 & 47 \\
\hline Non-indigenes & 5 & 5 & 9 & 9 & 4 & 4 & 36 \\
\hline Political Actors & 6 & 8 & 8 & 6 & 8 & 6 & 42 \\
\hline Total & 20 & 22 & 26 & 20 & 21 & 16 & $\mathbf{1 2 5}$ \\
\hline
\end{tabular}

Source: Fieldwork 2020

\section{Data collection}

Extensive literature review on political discrimination, inequality, identity, indigenes and non-indigenes, citizenship, indigenous law and political participation was carried out. I sought the consent of participants in the three selected regions where the study was carried out. Qualitative method of data collection was adopted in this study. Unstructured interview guide was designed to collect data from one hundred and twenty-five participants. The interview guide contained questions on political processes such as selection of candidate for election, voting pattern, participation, exclusion and inclusion. I made attempts not to ask emotionally laden questions that could inflate political tension in the areas selected for this study. I gave information sheet and consent form to the participants before data collection. The data collected was stored safely in my laptop and pass-worded. Also, collected data was saved in the data storage of email account designated for this study

\section{Data Analysis}

Qualitative method of data analysis was adopted. Themes were generated for codding processes. The following themes were generated from literature review and fieldwork: selection of candidate for election; voting pattern; participation; exclusion; and inclusion. The coded data was fed into NVIVO for descriptive and analytical explanations.

\section{Findings}

Explanations on findings flowed from coded analysis that was earlier subjected to NVIVO. Findings were based on the following themes: selection of candidate for election; voting pattern; participation; exclusion; and inclusion.

\section{Selection}

Selection of candidate for elections did not base on the dictates of the constitution. It was based purely on sentiment and discrimination. The participants in this study identified yardsticks for selecting participants in the election such as ethnicity, paternity and godfathers. The Constitution of the Federal Republic of Nigeria stipulates that an individual can be voted for if he / she had spent at least 10 years in a particular community or region. The dictate of the constitution is different from the peoples' practice. A non-indigene interviewed in Suleja said:

I have a nasty political experience here. I was allowed to participate in politics but I was not allowed to take part as a party representative into an elective office. The reason is simple; I am not an indigene of Suleja. I am from an Igbo but I was born in this great city.

His response resonated with another participant interviewed in Osogbo on ethnicity and political participation.

Let me say the obvious, I am from the north, Kebbi State precisely, I was denied the opportunity of representing this community at the local level. We are majority in "Sabo" here but the fact that I am not a "Yoruba" robbed me the opportunity of representing this community.

Similar concerns were expressed by a non-indigene participant in Owerri. She said she was married to an Igbo man for over twenty-five years but she was not allowed to participate in elective office.

I know that I have political sagacity. The entire community here knows this. But, you will be surprised, the community never allowed me to contest for an elective post. Usual words from our political party was that "it is a pity; you are not from here. You can only be an elected officer if you're a naturally born into this community".

Responses from participants in Lagos State quit different. Equal participation was allowed among indigenes and nonindigenes. The reason could be as a result of the fact that the status of Lagos State is different from other states selected for this study. Lagos State was the Federal Capital 
of Nigeria. The city is cosmopolitan in nature. It accommodates other ethnic groups in the country. A political actor that was interviewed in Lagos State responded:

We allow equal political participation here in Lagos State. We don't discriminate here. We follow due process in Lagos. Constitution dictates what, how and why select a participant for an elective office. Do you know that Igbo indigenes had represented this city at the House of Assembly even, two or three of them had represented Lagos State the federal constituency? We place competency upon ethnicity in Lagos State.

From the above, it was found that selection of candidates for elective posts was based on prejudice such as ethnicity, age, paternity, and other sentiments. It was also discovered in this section, that a community- Lagos State put competence ahead of primordial sentiments.

\section{Voting Patterns}

The reflection of voting patterns was explored in this subsection; it was tilted towards ethnicity. Participants revealed that the national politics is colored with ethnicity. Ethnicity determines who to be voted for. The said that differences between national and local politics were dictated by ethnicity, godfather and patronage. At the local level, participants revealed that pattern of voting follows "highest bidder" arrangement. If you have chunk of money to distribute to electorates, they will cast their votes to you. However, some of the participants also revealed that family linage and place of birth also determined voting pattern at the local level. A political actor interviewed in Owerri said:

My people voted for me because I am their own. They trust me and I have confidence in them. My opponent could not even win a polling unit. Our people alleged that he was not part of them. Though he has spent up to twenty years in this community.

Another participant in Osogbo said that there were no guiding principles in the local and national politics. He revealed that votes went to the highest bidder. According to him:

I don't think people considered development and future of this community. Votes usually go for those that can give money. The irony of the whole arrangements is that politicians distribute money at every election. For example, if you collected \#4000 (\$10) during the election, you will wait for another year before you can get another \#4000
(\$10). This explains poverty and lack of political culture.

Performance as a determinant of voting patterns was discussed by some participants. The participants in Lagos State revealed that they don't consider ethnicity or place of birth before you were voted for. The said that their choice of candidates and patterns of voting are dictated by performance and ability to deliver.

I know that politic with ethnicity played a major role in people's political interactions in the country. I want you to know one thing Lagos is different. We don't play politics because of ethnicity. Everyone is allowed to vote and voted for. What we usually considered in Lagos State is your ability to contribute meaningfully, I say it again, meaningfully to the development of this state.

Another participant interviewed in Ikeja said that apart from performance, strong community base determines whether you are going to win in an election or not. They said that the choice of candidate depends on acceptability among the community member. He explained this in terms of number of political office holders elected and appointed into various positions at wards, local government and state levels. He said:

My friend, we are politically sophisticated in Lagos State. We don't care about your place of birth. Our concern is what you can offer. As I speak, we have non-indigenes as unit heads, ward councilors, members of house of Assembly, Members of House of Representatives. In total we have over 20 political appointees and political office holders' non-indigenes representing Lagos State at different levels.

Participants interviewed in Owerri explained how monetary inducement played uncanny role in political participation. They said that choice of candidates for political offices does not follow democratic ethos. It is usually follow heavy bribery and' heavy bag'. Candidates usually bribe electorates and election umpires to compromise election results. They even explained how security officers collaborated with politicians to thwart electoral processes. An indigene of Owerri who participated in the in-depth interview lamented:

Selection is better than election in this state. Our electoral processes are far away from democratic processes. If you can bribe your way, people will vote for you. The most difficult aspect of our electoral processes is selection of a candidate to vie for elective posts. If you are not an aborigine, nobody will select you. 
Five interviewees, that is, one indigene, one political actor, three non-indigenes emphasized that political processes in Suleja are based on discrimination. They said that voting patterns akin to sentiment. It will be difficult for one to be nominated for an elective office, if the person is not an indigene. They also revealed that if you not a Muslim or a true born of Suleja aborigine, no one will nominate you as a candidate. Non-indigenes are only allowed to vote. But the voting pattern in Suleja remain the same. It must follow the pattern agreed upon by the indigenous people. A political actor interviewed in Suleja retorted:

It is dangerous to vote according to one's consciousness here. If one likes his / her life. He / she has to follow the voting pattern of the community. Political participation on the basis of equality ends at registration.

In this section, the researcher came up with voting patterns as reported by the participants in selected locations. They revealed that voting patterns were influenced by factors such as ethnicity, favoritism, godfather, bribery and others. I noticed that It was only in Lagos State that politics seems participatory and follows democratic principles. Everybody was carried along, politics is based on what individual can offer in terms of development and progress.

\section{Recognition}

Non-indigenes suffered non-recognition in scheme of things in the areas where the study was carried out. Nonindigenes were not recognized in political arrangements. Participants in the selected areas lamented how they were sidelined and threated like outside in the realm of politics. Participants said they have been living together and contribute immensely to the community. They argued that instead of recognition; they have been facing frustration, abandon, neglect and maginalisation. Anti-political participations tendencies had resulted mostly into nonparticipatory nature of politics in some areas selected for this study. Some participants, especially in Owerri and Suleja lamented that religion and ethnic identity as related to individual name(s) were ascribed to their non-inclusion as political flag-bearer nominees. They revealed that their host community only needed them to swell their numbers for political gains. A non-indigene who participated in the interview in Suleja lamented over non-inclusion and discrimination:

People don't see us as part of them. I was born in Suleja. I schooled here and I don't know other place as home except Suleja. The irony of it is that I cannot contest for an elective office here. They will ask me to go to my father's state / community.

A female participant looked as political participation from gender perspectives. She said that she was not recognized as part of them in this community. They usually referred her to a place of origin when it comes to political office sharing. She said:

Imagine, I relocated to this community after marriage. I am a women leader. We worked together for our candidate to emerge. Sharing of political office was based on state of origin. My party supposed to give me a political office. It was painful to hear that I cannot take up political office because I am not from this community.

In this subsection, non-indigenes suffered non recognition politically. The recognition was based on sentiment such as place of birth, gender and avarice.

\section{EXCLUSION AND INCLUSION}

Participatory democracy has to do with inclusion. Most of the participants in this study lamented that they were excluded from scheme of political arrangement. The reasons put forward by the participants including ethnicity, religion and godfathers. The participants who were female exposed the gendering of political participation. The female participants said that society sees female politician as outcasts and they usually discriminated against. A nonindigene in Owerri who is a female lamented:

The reason for my exclusion from holding a political office has to do with my place of origin. It was because I only married here. I was born in other region to non-indigene.

A political office holder in Ikeja viewed it from competition angle. He said:

Each region, state and zone has competent people to hold political offices. My thinking is that available political offices should be shared among indigenes before non-indigenes could be considered. The non-indigenes have their state, region and zone. They should go back to their places to contest and hold political office.

A participant in Suleja, who has been living in the area for over twenty years explained exclusion from religion point of view. He lamented that he was not allowed to contest elections because he belief is different from most party members in that area. He retorted:

Why some party members depended on religious belief to determine one's political fate. I don't have to hide my faith. I belief in traditional worship. I prefer worship the god of thunder (sango). Our party members fear traditional gods than the foreign God (Christianity and Islam). 
Another participant in Owerri, provided a similar view on exclusion from holding political office on the basis of religion. He pointed out:

Naturally, people will not vote for you if you have a different religious view. It amounts to waste of time and resources to contest if you have a different religious affiliation from the locals.

Some participants examined political exclusion and inclusion based on godfathers' influences. They explained that it was a man-knows-man arrangement. Participants lamented that the bane of political participation today in Nigeria is the influence of godfathers. They said that partisanship has robbed the country of competent leaders. Until the nation is placed on specification rather than diffusion, achievement rather than ascription before it can be moved forward. A non- indigene interviewed in Osogbo stated:

Political participation has to do with godfathers supporting you. If you don't have someone to stand for you, it will be difficult to get the party's nod. You must have a political god-father that you must report to on getting to the office before your party can allow you to vie for a political office.

An indigene of Owerri revealed another dimension to political participation. He opened up a discussion that has no scientific basis. According to him, many politicians used diabolic means to get party nomination and enter into unholy agreement with godfathers. He said:

Can you imagine you may be asked to join occultism and swear an oath for you to be selected and become a party flag bearer? If you are not ready to do these, your party will not nominate you. I have to be frank with you, I was taken to a shrine and swear before I was given a ticket.

Inclusion is very important and central to my discussion in this paper. Participants in this study looked as upholding of the Constitution as a major tool that can ensure political participation. They revealed that constitution recognizes individual rights but political players failed to follow the dictate of the Constitution. A political actor in Ikeja when responding to a question on political inclusion, he said:

I believe the country can move forward socially, economically and politically if the political players uphold the constitution dictates. We need to uphold the ten years on living a particular location to encourage political participation.

Participants suggested that names identified with religion affiliation should be derecognized such as James, Mohamed, Isaac, Jabir and host of others. Participants also suggested that ethnicity, age, place of origin should be de- emphasized in any national interaction. An indigene who is living Ilorin responded:

We all know the factors that are dividing us. These factors also encouraged non-inclusion in politics such as discrimination based on state of origin, ethnicity and age. We need to drop all these divisive tendencies, if we want to move forward politically.

I asked questions on what could bring political inclusiveness. Participants identified the following such as removal of ethnicity, religion division and obliteration of godfathers. Participants stated that political inclusiveness can be promoted based on recognition and constitutionalism. Participants opined that it will be difficult to have equal political participation, inclusiveness and probity until political players follow the dictates of the constitution.

\section{CONCLUSION}

This study was set out to examine political participation among Nigerians on equal basis. It looks at factors that could bring political inclusiveness through in-depth interviews across Nigeria. Participants in this study were drawn from segments of the society such as indigenes, non-indigenes and political actors. As noted above, nonrecognition formed the basis of political discrimination in Nigeria. This paper used Recognition Theory to explain reasons why some people excluded from political participation in Nigeria. Politics of recognition denominates modern day politics (Taylor, 1992). It was discovered in this study that ethnic conflict is a common feature political affair in the country. In this study, it was also observed that political marginalisation and power struggles have polarized political development. Most times, lack of focus and direction dominated politics. Participants in this study felt that government and political players were to blame because they benefitted from divisions. The participant revealed that politics of divideand-rule exacerbated ethnic-discrimination in politics.

In this study, however, the evil of inequality and political discrimination were identified among other factors such as ethnicity, paternity and godfathers. These factors formed the bases for selection of candidate for elections. Some aspects of national life that were related to politics of ethnic discrimination also affected political participation. This paper, therefore, concluded that voting patterns as reported by participants in selected locations influenced by factors such as ethnicity, favoritism, godfather, bribery and others. Candidate choice for elections is determined largely by godfather, ethnicity, age, religion rather that a ten-year residency dictated by the Constitution. Therefore, 
inclusiveness without discrimination such as ethnicity, region, godfather, state of origin and gender may galvanize equal political participation. This paper finally concluded that political participation though inclusiveness can reduce politics of ethnic-discrimination in Nigeria.

\section{ACKNOWLEDGEMENT}

This study was sponsored by the Tertiary Education Trust Fund (TETFund) through the Adekunle Ajasin University, Akungba Akoko Ondo State, Nigeria.

\section{REFERENCES}

[1] Appiah, K. (1994). Identity, Authenticity, Survival. Princeton, NJ: Princeton University Press.

[2] Chatterjee, P. (1986). Nationalist thought and the colonial world. Minneapolis: University of Minnesota Press.

[3] Davies, A., Danmole, H., \& Taiwo, I. (1995).Contemporary issues in Nigerian affairs. Ibadan: SUNAD Publishers.

[4] Dyde, S. W. (2001).Philosophy of Right: G. W. F. Hegel. Kitchener, Ontario: Batoche Book.

[5] Egbosiuba, M. (2012).Constitutional Amendment and Quest for More States in Nigeria. All Things Nigeria.Allthingsnigeria.com. Retrieved 17 June 2015, from http://www.allthingsnigeria.com/2012/constitutionalamendment-and-quest-for-more-states-in-nigeria

[6] Everyculture.com. (2007). Culture of Nigeria - history, people, clothing, traditions, women, beliefs, food, customs, family. Retrieved 17 June 2015, from http://www.everyculture.com/Ma-Ni/Nigeria.html

[7] Falola, T. (1999). The history of Nigeria. Westport, Conn: Greenwood Press.

[8] Falola, T., \& Heaton, M. (2008). A history of Nigeria. Cambridge, UK: Cambridge University Press.

[9] Fraser, N. (1997). Justice interruptus. New York: Routledge.

[10] Fraser, N. (2001). Recognition without Ethics?Theory, Culture \& Society, 18(2-3), 21-42. doi: $10.1177 / 02632760122051760$

[11] Fraser, N. (2007). Feminist politics in the age of recognition: A two-dimensional approach to gender justice studies. Social Justice, 1(1).

[12] Fraser, N., \& Honneth, A. (2003). Redistribution or recognition? London: Verso.

[13] Hamzat, A. (2012). The historical challenges of Nigeria's amalgamation/religion and the way to peace (Part 2).TheNigerianVoice. Retrieved 17 June 2015, from http://www.thenigerianvoice.com/nvnews/97312/1/thehistorical-challenges-of- nigeriasamalgamation.html

[14] Honneth, A. (1992). Integrity and Disrespect: Principles of a Conception of Morality Based on the Theory of Recognition. Political Theory, 20(2), 187-201. doi:10.1177/0090591792020002001

[15] Honneth, A. (1995). Patterns of Intersubjective Recognition: Love, Rights, and Solidarity by Axel Honneth 1995. Ethicalpolitics.org. Retrieved 15 June 2015, from http://ethicalpolitics.org/blackwood/honneth.htm

[16] Honneth, A. (2001).Recognition or Redistribution?Changing Perspectives on the Moral Order of Society.Theory, Culture \& Society, 18(2-3), 43-55. doi:10.1177/02632760122051779

[17] Honneth, A. (2007). Disrespect. Cambridge: Polity Press.

[18] Jekayinfa, A. (2002). Implications of competitive ethnicity in the process of nation building in Nigeria.Nigerian Journal of Social Studies, 6(1). Retrieved from http://www.unilorin.edu.ng/publications/jekayinoluwa/21.I MPLICATION\%20OF \%20COMPETITIVE.htm

[19] Laitinen, A. (2002). Interpersonal Recognition: A Response to Value or a Precondition of Personhood? Inquiry, 45(4), 463-478. doi:10.1080/002017402320947559

[20] Margalit, A. (2001). Recognition: Recognizing the Brother And The Other: Avishai Margalit. Aristotelian Society Supplementary Volume, 75(1), 127-139. doi:10.1111/14678349.00082

[21] Markell, P. (2000). The Recognition of Politics: A Comment on Emcke and Tully. Constellations, 7(4), 496-506. doi:10.1111/1467-8675.00205

[22] McQueen, P. (2011). Recognition, Social and Political, In James Fieser \& Bradley Dowden (eds.).Internet Encyclopedia of Philosophy. Retrieved 01 September 2015, http://www.iep.utm.edu/recog_sp/

[23] Morrison, Z. (2011). Social inclusion, diversity, and the politics of recognition.Insights.

[24] Insights, 10(1).

[25] Mustapha, A.R (2006) Ethic structure, inequality and Ggovernance of the public sector in Nigeria. Democracy, governance and human rights programme paper. www.unrisd.org

[26] Nwakikagile, G. (2001). Ethnic Politics in Kenya and Nigeria. Sandyford, Ireland: Nova Publishers

[27] Ojukwu, C., \& Nwaorgu, F. (2013). Ethnic Elite Organisation and Political Transitions in Nigeria: Ohanaeze Ndigbo in Perspective. Canadian Social Science, 9(1). doi:10.3968/j.css.1923669720130901.9555

[28] Okolo, P. (2008). Ethnic Relations and Violent Conflict in the Niger Delta: The Case of the Urhobo, Itsekiri and Ijaws of Delta State, Nigeria. SSRN Journal. doi:10.2139/ssrn.1723221

[29] Robinson, K. (1961). The Making of British Nigeria Sir George Goldie and the making of Nigeria.By John E. Flint. London: Oxford University Press, 1960. Pp. xiv, 340, illus. and maps. 30s. Lugard: the years of authority, 1898-1945. By Margery Perham. London: Collins, 1960. Pp. xx, 748, illus. and maps.50s. J. Afr. Hist, 2(02), 332.doi:10.1017/s0021853700002553

[30] Sagay, I. (2004).Nigeria: federalism, the constitution and resource control. Speech, Lagos.

[31] Stern, R. (2002). Hegel and the phenomenology of spirit. London: Routledge.

[32] Taylor, C. (1992). Politics of Recognition. Retrieved from http://elplandehiram.org/documentos/JoustingNYC/Politics of_Recognition.pdf

[33] World Leader.(2003). Nigeria - Political background.In Nations Encyclopedia.Nations Encyclopedia.

[34] Young, I. (1990). Justice and the politics of difference. 
Princeton, N.J.: Princeton University Press. 